\title{
sciendo
}

\section{What BENEFITS DOES TransPaRENT LOBbying BRING}

\author{
Pavla Bednářová ${ }^{1}$
}

\begin{abstract}
Most quantitative studies deal with the costs of transparency lobbying and give little or no attention to quantifying the benefits. The aim of the article is to determine options for increasing lobbying transparency and their evaluation and comparison from the viewpoint of direct and indirect benefits. Regulatory Impact Analysis (RIA) is used. Five basic options are identified. Option $\mathrm{I}$ is the possibility of increasing the transparency of lobbying by measures introduced on lobbyists. Option II represents an increase of transparency in terms of lobbying targets. Option III is defined as an increase in lobbying transparency by means of sunshine principles and the increase of lobbying transparency by monitoring and sanctions is included in Option IV. All five options are evaluated from the perspective of realized direct and indirect benefits. The selection of the most suitable option will be carried out in relation with the presupposed incurred regulatory costs of lobbying transparency increase.
\end{abstract}

\section{Keywords}

Transparency, Lobbying, Regulatory Impact Analysis, Cost Benefit Analysis, Regulatory Benefits

\section{Introduction}

The article has been written as an integral part of the evaluation of the project focused on increasing lobbying transparency as part of the GAČR grant "Impact of Transparency of Lobbying on Democratization and Its Consequences".

Most quantitative studies deal with the costs of transparency lobbying and give little or no attention to quantifying the benefits. P. Bednárová (2018) theoretically defined the regulatory costs associated with transparent lobbying in the article How Expensive Transparent Lobbying Is. For the policymaker, it is important to compare the estimated costs alongside the benefits and it is particularly important where change is intended to improve economic welfare. The aim of the article is to identify the benefits associated with

\footnotetext{
${ }^{1}$ Technical University of Liberec, Faculty of Economics, Voroněžská 13, 46001 Liberec, Czech Republic. E-mail:
} pavla.bednarova@tul.cz. 
transparent lobbing: to determine options for increasing lobbying transparency and their evaluation from the perspective of realized benefits.

Lobbying as a term can be defined in a lot of ways. In essence, however, it always involves advancing the interests of a particular interest group in the course of a decision-making process. A definition which is often considered the most precise is that by L. Graziana (2001, p. 248): "Lobbying is a specialised and professional representation of interests by means of a wide variety of tools which in principle eliminate a corruptive change of services. It is by its nature very different from a general non-specialised representation provided by elected representatives. As a representative of particular interests a lobbyist provides information and technically-professional expertises which can be useful and sometimes decisive for defining legislative and administrative regulation." In addition to this, there is Schendelen's definition stating that "Lobbying refers to the various types of unconventional behaviour of interest groups focused on achieving requested results" (Van Schendelen, 2002, p. 210). In 2006, the European Commission (hereinafter Commission) issued a document called Green Paper - European Transparency Initiative. This document formulates relatively broad definition of lobbying: "All activities carried out with the objective of influencing the policy formulation and decision-making processes of the European institutions" (Commission, 2006, p. 5). Š. Laboutková and M. Žák (2010, p. 2) delimited the basic attributes of lobbying when "lobbying is first of all focused on advancing interests, it is indispensable source information and the biggest problem is to distinguish lobbying from corruption". Lobbying helps to articulate and advance the interests of various parts of society and it is at the same time an information channel by means of which the knowledge of the holders of the public power about decisive facts is improved. Affecting representatives of the public power with the aim of influencing their decisions is not always transparent and carried out according to clear rules, which brings the risk of public interests being manipulated in favour of hidden partial interests. Strengthening the transparency of the legislation and decision-making process helps to reveal the influence and the relations between lobbyists and interest groups on the one hand, and public entities on the other, to public control, which should contribute to the reduction of the negative impacts often connected with lobbying, such as corruption, conflict of interests, protection and clientelism. However, greater openness and transparency on public policy formulation, development and decision-making is considered central to securing more effective public governance. According to OECD (2013), creating limits for transparent lobbying is also essential for the integrity of the public decision-making process. Š. Laboutková and P. Vymětal (2018a) proposed a catalogue of currently used measures dealing directly or indirectly with lobbying regulation that support the transparency principle in general. All measures are grouped in four logical categories (see Table 1). 
DOI: 10.2478/danb-2018-0012

Table 1: Main categories on lobbyists' transparency

\begin{tabular}{|c|c|c|c|}
\hline Category & Chapter & Data/information & $\begin{array}{c}\text { Number } \\
\text { of indicators }\end{array}$ \\
\hline \multirow{4}{*}{ Lobbyists } & 1 & Register & 14 \\
\hline & 2 & Codes of Conduct & 8 \\
\hline & 3 & Disclosure of activities & 7 \\
\hline & 4 & Open calendars & 2 \\
\hline \multirow{5}{*}{$\begin{array}{c}\text { Targets } \\
\text { of lobbying }\end{array}$} & 5 & Codes of Conduct & 14 \\
\hline & 6 & Revolving doors & 7 \\
\hline & 7 & Conflict of interests & 5 \\
\hline & 8 & $\begin{array}{l}\text { Disclosures of politicians / } \\
\text { senior public employees }\end{array}$ & 3 \\
\hline & 9 & Appointment diaries & 9 \\
\hline \multirow{7}{*}{$\begin{array}{l}\text { Sunshine principles / } \\
\text { sunshine rule }\end{array}$} & 10 & Rules on legislative process & 17 \\
\hline & 11 & Rules on decision-making & 6 \\
\hline & 12 & Rules on consultations & 10 \\
\hline & 13 & Legislative footprint & 6 \\
\hline & 14 & Open Government Data & 12 \\
\hline & 15 & Political parties funding & 9 \\
\hline & 16 & Freedom of information & 10 \\
\hline \multirow{2}{*}{$\begin{array}{c}\text { Monitoring } \\
\text { and sanctioning }\end{array}$} & 17 & Oversight & 7 \\
\hline & 18 & Sanctions & 13 \\
\hline
\end{tabular}

Source: Laboutková, Š. and P. Vymětal (2018a) 


\section{Aims and Methods of the Research}

As far as the evaluation of increased lobbying transparency is concerned, the most commonly used are input-output methods including economic analyses, specifically Cost-Benefit Analysis (CBA), which is the core method of Regulatory Impact Analysis (RIA). RIA is a systemic approach to critically assessing the positive and negative effects of proposed and existing regulations and non-regulatory alternatives. The economic rationale for the use of RIA derives from its expected impact in increasing the effectiveness and efficiency of regulatory interventions and thus economic welfare. All RIA can be considered to be based on the use of the cost/ benefit principle. This means that the objective of conducting RIA is to try to ensure that regulation is only made when the benefits of the regulation are larger than the costs it imposes. The Recommendation of the Council on Regulatory Policy and Governance (OECD, 2012) recommends that RIA be integrated into the early stages of the policy process in the formulation of new regulatory proposals.

The economics of regulation presents three different dynamics that explain the rationale for the adoption of RIA. The first is delegation. Regulatory intervention is characterised by a problem of delegation when a principal (the parliament or other legislative authorities) delegates authority to produce regulation to an agent (i.e. a ministry or other agencies). In rational choice theory (Simon, 1955; Laffont and Martimort, 2009). the principal-agent model helps in understanding the rationale for RIA. Once power has been delegated, information asymmetries produce agency dominance, and agencies may produce rules that do not reflect the approach adopted (or outcome sought) by the principals. However, the likelihood that agencies will develop rules that are consistent with the views of the principals is enhanced if proper administrative procedures (such as RIA) are introduced (McCubbins et al., 1989). Posner (2001) suggests that Cost-Benefit Analysis (CBA) should be used to control agency behaviour, minimising error costs under conditions of information asymmetry. Thus, the use of RIA limits the potential influence of self-seeking interest groups by reducing the principal-agent slack and in assuring that agencies are responsive to the principal's interest. The second is democratic governance. Neo-pluralist theory (Manley, 1983; Arnold, 1987) suggests that regulatory policy tools (such as RIA) should be used to change the framework in which actors (the executive, agencies, and the pressure groups, including civil society associations) interact so that the rulemaking process is more open to diffuse interests and more accountable to citizens. RIA is adopted to help to ensure that all the major interested parties are heard in the policy-making process. The third is rational policy making. The adoption of RIA helps in fostering regulations that increase the net welfare of the community (Arrow et al., 1996). This perspective is consistent with the civic republican theory (Sunstein, 1993; Ayres and Braithwaite, 1992) which argues that, under proper conditions, actors in the regulatory system are able to systematically pursue the broader community interest. Thus, the use of RIA ensures the engagement of public interest groups, civil society organisations, and citizens and enhances the likelihood that regulatory outcomes will be consistent with the requirements of the normative theory of regulation. 
RIA is a comparative process; it is based on determining the underlying regulatory objectives sought and identifying all the policy interventions that are capable of achieving them. These "feasible alternatives" must all be assessed, using the same method, to inform decision-makers about the effectiveness and efficiency of different options and enable the most effective and efficient options to be systematically chosen. As a methodology, Cost-Benefit Analyses represents the "best practice" for RIA. Because it is based on quantifying benefits and costs in monetary terms and comparing them over a suitable period of time, it provides a strong basis for comparing alternatives and for guiding decision-makers on the likely implications of different options. It is very common in RIA to find that important benefits and costs cannot be quantified. However, if the CBA approach is used in such cases, a "partial" CBA can be generated. This can still be very useful to decision-makers as it narrows the range of issues that must be dealt with through more subjective, qualitative analysis. Thus, developing even an incomplete CBA can greatly improve decision-making. Even where it is able to quantify relatively few costs (or benefits), using CBA's systematic approach to try to ensure that all benefits and costs have been identified and assessed will help to improve the quality of advice to decision-makers. The task of identifying benefits will usually be much easier than that of identifying costs, since the expected benefits constitute the reasons that the regulations were proposed in the first place. However, determining the size of these benefits and, in particular, trying to express them in monetary terms can be very difficult. This is because many regulatory benefits involve things that do not have obvious market value. However, even if benefits are not to be expressed in monetary terms, it is important to try to estimate the size of the benefits. According to the OECD (2002, p. 47): “... RIA's most important contribution to the quality of decisions is not the precision of the calculations used, but the action of analysing questioning, understanding real world impacts and exploring assumptions".

\section{Results of the Research}

In connection with the determination of the benefits of an increase in lobbying transparency by means of the proposed measures (see Table 1), the individual solution options are defined. The option with the most suitable solution should set such conditions for the performance of lobbying which will significantly contribute mainly (Government Office of the Czech Republic, 2017, p. 19):

- to the definition of the term "lobbying",

- to the determination of a circle of people involved in lobbying (lobbyists) and of public officers whose conduct lobbyists influence,

- to setting up rules for transparent lobbying,

- to the general increase in the transparency of the decision-making and legislative process. 


\section{Option 0 - non-transparent lobbying}

Option zero represents the existence of non-transparent lobbying without adopting any measures for any increase in decision-making and legislative process transparency. The risk arising from retaining the non-transparency state is a negative impact on the creation of public policies and adoption of decisions from the viewpoint of the potential advancing of hidden interests or giving preference to certain interests over others and also on the public, whose confidence in these processes decrease. Public decisions or activities of public institutions then lose their legitimacy. Other risks include democracy erosion, decrease of citizen confidence in politics, political parties and institutions. It can be assumed that the problems of the current condition will become worse and deeper, namely (Government Office of the Czech Republic, 2017):

- the lingering low transparency of the legislation process, which will lead to the gradually deteriorating quality of legal regulations;

- pressure coming from interest groups and aimed at reaching such legislation which would be advantageous mainly for the groups themselves;

- as a consequence, the quality of the business environment will deteriorate and also the attractiveness of the Czech Republic not only for foreign investors (including the risk of international arbitrations due to breaches of agreement on the mutual protection of investments), but also for Czech companies (including the outflow of Czech companies' headquarters out of the Czech Republic);

- low level of decision-making processes transparency (strategic planning, awarding tenders, etc.) in public administration (state administration and public corporations);

- low level of control over the influence on the decision-making of entities in public power.

The benefits associated with maintaining the current state are shown in Table 2.

Table 2: Benefits connected with Option 0 - non-transparent lobbying

\begin{tabular}{|c|c|}
\hline \multirow{4}{*}{ Option 0} & Direct benefits \\
\hline & $\begin{array}{l}\text { - absence of costs arising from regulation incurred by the addressees of regulation } \\
\text { and the public sector, } \\
\text { - no increase in administration. }\end{array}$ \\
\hline & Indirect benefits \\
\hline & $\begin{array}{l}\text { - no intervention into the private sector of natural persons in the form of personal } \\
\text { data disclosure. }\end{array}$ \\
\hline
\end{tabular}

Source: author; Government of the Czech Republic, $2017 \mathrm{~b}$ 


\section{Option I - increase in lobbying transparency on the part of lobbyists}

This option represents the adoption of measures for the increase in lobbying transparency which are performed on the part of lobbyists. Lobbyists are persons who systematically and in an organized way endeavour to influence the legislative process and decision-making of public officials (Government Office of the Czech Republic, 2017a). They are entities (legal or natural persons) focusing primarily on lobbying (professional lobbyists include lobbyist consultants and associations, then legal counsels and law firms) and entities involved in lobbying as in supporting activities for the purpose of support of their main activity or business (in-house lobbyists, thus e.g. professional associations, non-profit organizations, etc.).

The proposed measures (see Table 1, measures 1-4) include Register, Codes of Conduct, Disclosure of activities and Open calendars. The individual measures can be realized by means of legislative regulations (legally binding and enforceable measures), or they may be left to the discretion of stakeholders (non-legislative measures). These measures are among the most frequently used tools ensuring public control over lobbying activities and increasing lobbying transparency. The regulatory benefits connected with Option I are summarised in Table 3 below.

Table 3: Regulatory benefits connected with Option I - increase in lobbying transparency on the part of lobbyists

\begin{tabular}{|c|c|}
\hline Option I & $\begin{array}{l}\text { Direct benefits } \\
\text { - relatively low costs of the establishment of a register, the use of existing } \\
\text { authorities, } \\
\text { - relatively low costs of the establishment of a public diary, } \\
\text { - low transaction costs of information acquisition, } \\
\text { - absence of costs associated with legislative measures introduction }(\mathrm{N}), \\
\text { - absence of costs associated with enforcing legislative measures }(\mathrm{N}) \text {. } \\
\text { Indirect benefits } \\
\text { - recognition of lobbying as a legitimate and useful part of the political process, } \\
\text { - restrictions on lobbying, and/or reducing its intensity, } \\
\text { - public access to data about lobbying activities, } \\
\text { - restriction of the influence of illegitimate influence groups, } \\
\text { - allowing public officials to know who is trying to influence them or others in } \\
\text { authority, } \\
\text { - levelling the playing field among groups attempting to influence governmental } \\
\text { decision making, } \\
\text { - positive signal towards society about the effort to set ethical standards. }\end{array}$ \\
\hline
\end{tabular}

Source: author; Government of the Czech Republic, 2017b; Laboutková, ̌̌. \& P. Vymětal, $2018 b$ Note: (N) measures of a non-legislative nature 


\section{Option II - increase in lobbying transparency from the point of view of lobbying targets}

The second option is focussed on the increase in lobbying transparency on the side of lobbying targets. These are mainly the subjects of lobbying, i.e. public officers who include members of parliament, government members, high officials but advisors and assistants of public officers (mainly of parliament members and senators) can also be included. Depending on the width of the conception of lobbying, representatives of local governments, i.e. of municipalities and regions, could also be included as subjects of lobbying who are also involved in decision-making about significant issues of the public interest, e.g. public tenders, landscape planning, etc. (Government Office of the Czech Republic, 2017a).

An increase in lobbying transparency can be achieved by adopting measures 5-9 (see Table 1), which are Codes of Conduct, Revolving doors, Conflict of interests, Disclosures of politicians/senior public employees, Appointment diaries. The individual measures may again take the form of legislative or non-legislative measures. In Table 4 the regulatory benefits connected with Option II are defined.

Table 4: Regulatory benefits connected with Option II - increase in lobbying transparency from the point of view of lobbying targets

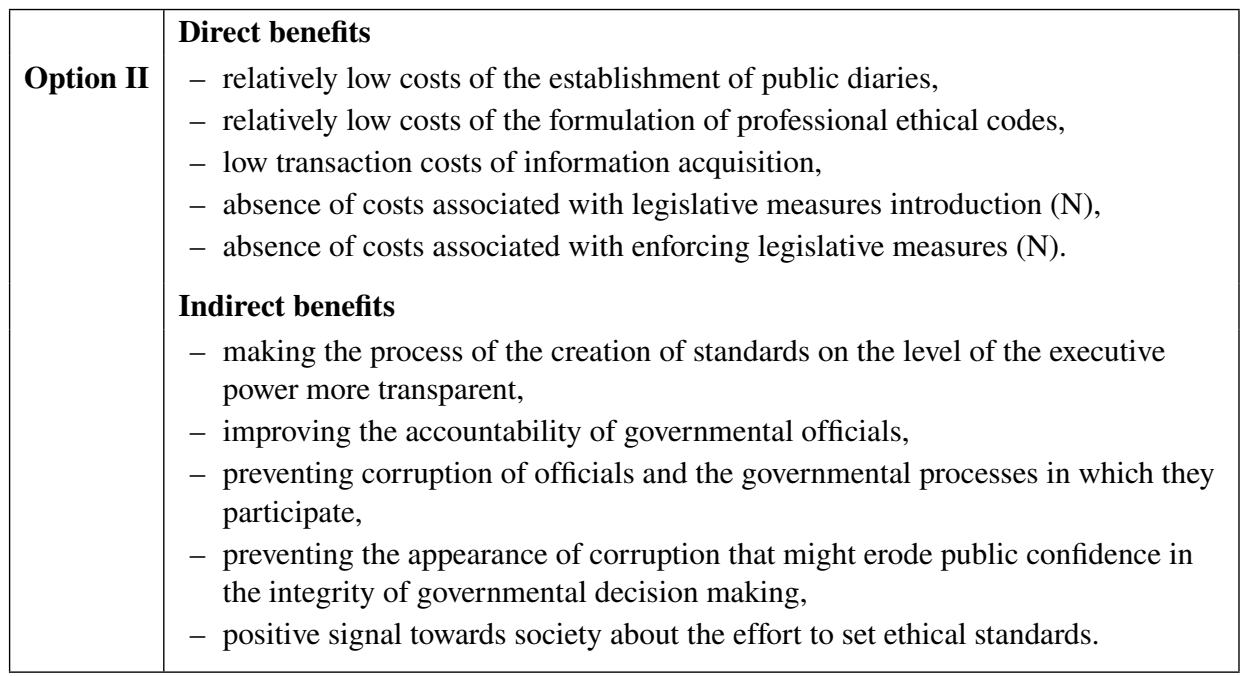

Source: author; Government of the Czech Republic, 2017b; Laboutková, Š. \& P. Vymětal, $2018 b$ Note: (N) measures of a non-legislative nature 


\section{Option III - increase in lobbying transparency by means of sunshine principles}

In the case of the third option, the increase in lobbying transparency is achieved by means of so-called sunshine principles in legislative or non-legislative form. By means of adopting and complying with these rules, an increase in transparency is achieved in all decision-making and legislative processes in the whole society. Sunshine principles are defined in Table 1. They are measures 10-16, i.e. Rules on legislative process, Rules on decision-making, Rules on consultations, Legislative footprint, Open Government Data, Political parties funding and Freedom of information. The regulatory benefits connected with Option III are included in Table 5.

Table 5: Regulatory benefits connected with Option III - increase in lobbying transparency in accordance with increase in transparency of decision-making and legislative processes

\begin{tabular}{|c|c|}
\hline Option III & $\begin{array}{l}\text { Direct benefits } \\
\text { - low costs associated with adopting non-legislative measures }(\mathrm{N}), \\
\text { - low transaction costs of information acquisition (legislative footprint, open } \\
\text { government data, rules for consultations), } \\
\text { - absence of costs associated with legislative measures introduction }(\mathrm{N}), \\
\text { - absence of costs associated with enforcing legislative measures }(\mathrm{N}) \text {. } \\
\text { Indirect benefits } \\
\text { - increase in transparency and public control over the legislative process, } \\
\text { - public sources of information regarding influence and its bearers, } \\
\text { - public control over the legislative footprint, } \\
\text { - support of integrity and increase in the efficiency of the creation of public } \\
\text { policy and decision-making processes, } \\
\text { - long-term positive effect in the case of introduction and good functioning } \\
\text { of sunshine principles, } \\
\text { - cultivation of internal political environment. }\end{array}$ \\
\hline
\end{tabular}

Source: author; Government of the Czech Republic, 2017b; Laboutková, ̌̌. \& P. Vymětal, $2018 b$ Note: (N) measures of a non-legislative nature

\section{Option IV - role of monitoring and sanctions in the increase of lobbying transparency}

In the fourth option, the costs of an increase in lobbying transparency are connected with functional monitoring and sanctions, i.e. measures 17 and 18 (see Table 1). Oversight and Sanctions are mainly connected with the adoption of legislative measures and the benefits are connected with the functioning of an inspection authority and with imposing and enforcing sanctions laid down in the event of a breach of the rules. A certain level of control can also be performed even in the case of measures on non-legislative nature. Table 6 lists the regulatory benefits connected with monitoring and sanctions. 
Table 6: Regulatory benefits connected with Option IV - role of monitoring and sanctions in the increase of lobbying transparency

\begin{tabular}{|l|l|}
\hline Option IV & $\begin{array}{l}\text { Direct benefits } \\
-\end{array}$ \\
& low costs associated with the use of existing authorities for monitoring, \\
- & relatively low transaction costs of information acquisition and comparison, \\
- & absence of costs associated with legislative measures introduction $(\mathrm{N})$, \\
- & absence of costs associated with enforcing legislative measures $(\mathrm{N})$. \\
Indirect benefits & - increase in the transparency of the legislative process, \\
- & public control over lobbying both on the central and regional level, \\
- & elimination of unfair influence of legal regulation by partial interests, \\
- & destigmatization of lobbing as a legitimate profession, \\
- & trust in societies which are based on respect for standards and rules, \\
- & a signal sent abroad and to international institutions regarding the fact that the \\
& phenomenon of lobbying is being solved.
\end{tabular}

Source: author; Government of the Czech Republic, 2017b; Laboutková, ̌̌. \& P. Vymětal, $2018 b$ Note: (N) measures of a non-legislative nature

The proposed measures for increasing lobbying transparency can work individually or in mutual combination, which can intensify their effects in practice. With regards to national specificities and historical approach, it is necessary to thoroughly consider which of the possible measures should be applied and in what forms so that the expected results can be ensured.

\section{Conclusion}

The aim of the article was to determine options for increasing lobbying transparency and their evaluation and comparison from the viewpoint of direct and indirect benefits. As far as the evaluation of increased lobbying transparency is concerned, the most commonly used is Cost Benefit Analysis, which is the core method of Regulatory Impact Analysis (RIA). RIA is a systemic approach for critically assessing the positive and negative effects of proposed and existing regulations and non-regulatory alternatives. RIA's most important contribution to the quality of decisions is not the precision of the calculations used, but the action of analysing, questioning, understanding real-world impacts and exploring assumptions. The used cost-benefit method was specified on the basis of the delimitation of characteristics and attributes of transparent lobbying which are: 1) Direct rules focusing on lobbyists in term of lobbying activities, both legal and self-regulation, 2) Indirect provisions rule subject of lobbying, 3) Sunlight principles and/or anti-corruption tools and 4) The monitoring and sanctioning system. The individual measures may take the form of legislative or non-legislative measures. 
First, a zero option was defined as the state of the current legislation and non-transparent lobbying. The direct benefits of option zero were connected with the absence of costs arising from the regulation and indirect benefits connected with preservation of privacy of individuals. Option I is the possibility of increasing the transparency of lobbying by measures introduced on lobbyists. There are benefits related to the establishment and operation of Register, Codes of Conduct, Disclosure of activities and Open calendars. There are relatively low costs involved in the establishment of a register, a public diary and the transaction costs of information acquisition. Option II represents an increase of transparency in terms of lobbying targets. The benefits are associated with the implementation of Codes of Conduct, Revolving doors, Conflict of interests, Disclosures of politicians/senior public employees, Appointment diaries. There are relatively low costs related to the establishment of public diaries and formulation of professional ethical codes. Option III is defined as an increase in lobbying transparency in accordance with an increase in the transparency of decision-making and legislative processes. The measures applied include Rules on legislative process, Rules on decision-making, Rules on consultations, Legislative footprint, Open Government Data, Political parties funding and Freedom of information. A large number of other benefits are associated primarily with non-legislative measures where there are no costs associated with legislative measures introduction and their enforcing. In the fourth option, the benefits of increase in lobbying transparency are connected with Oversight and Sanctions. The indirect benefits are connected with increasing the transparency of the legislative process, elimination of unfair influence of legal regulation by partial interests and destigmatization of lobbing as a legitimate profession. There is also a signal sent abroad and to international institutions regarding the fact that the phenomenon of lobbying is being solved.

The proposed measures for increasing lobbying transparency can work individually or in mutual combination, which can intensify their effects in practice. With regards to national specificities and historical approach, it is necessary to thoroughly consider which of the possible measures should be applied and in what forms so that the expected results are ensured. The selection of the most suitable option will be made in relation with the presupposed incurred regulatory costs of lobbying transparency increase.

\section{Acknowledgements}

This paper has been elaborated as one of the outcomes of research project supported by the Czech Science Foundation, project No. GA16-08786S "Impact of Transparency of Lobbying on Democratization and Its Consequences". 


\section{References}

Arnold, R. D. (1987). Political Control of Administrative Officials. Journal of Law, Economics, and Organisations, 3(2), 279-286.

Arrow, K. J. et al. (1996). Benefit-Cost Analysis in Environmental, Health and Safety Regulation. Washington, D.C.: American Enterprise Institute Press.

Ayres, I. \& Braithwaite, J. (1992). Responsive Regulation: Transcending the Deregulation Debate. Oxford: Oxford University Press.

Bednárová, P. (2018). How Expensive Transparent Lobbying Is. ACC Journal, 24(2). Liberec: Technická univerzita v Liberci.

Commission of the European Communities. (2006). Green Paper - European Transparency Initiative. Retrieved from http://europa.eu/documents/comm/green_papers/pdf/com2006_194_en.pdf.

EASA. (2011). Regulatory Impact Assessment (RIA) Methodology. Retrieved from https: //www.easa.europa.eu/sites/default/files/dfu/rulemaking-docs-procedures-and-work-in-structions-WI.RPRO.00046--Regulatory-Impact-Assessment-(RIA)-Methodology.pdf. Graziano, L. (2001). Lobbying, Pluralism, and Democracy. Basingstoke: Palgrave. Government of the Czech Republic. (2017a). Návrh věcného záměru zákona o lobbingu. Retrieved December 12, 2017, from https://apps.odok.cz/veklep-detail?pid=ALBSAQ2AK8RP.

Government of the Czech Republic. (2017b). Závěrečná zpráva z hodnocení dopadi̊ regulace (RIA) (k návrhu věcného záměru o lobbingu). Retrieved January 21, 2018, from https://apps.odok.cz/veklep-detail?pid=ALBSAQ2AK8RP.

Laffont, J. J. and Martimort, D. (2009). The Theory of Incentives: The Principal Agent Model. Princeton University Press, Princeton.

Laboutková, Š. and Žák, M. (2010) Lobbování v Evropské unii a v České republice. Politická ekonomie, 58(5), 579-594.

Laboutková, Š. and Vymětal, P. (2018a). Evaluation of Transparency of Lobbying as one of the Factors Reflecting the Institutional Quality. Journal of Public Policy. Under review. Laboutková, Š. and Vymětal, P. (2018b). A Black Box of Assessment of Institutional Quality: Evaluation of Transparency Lobbying as a Challenge. Forthcoming.

Manley, J. F. (1983). A Class Analysis of the Pluralism I and Pluralism II. The American Political Science Review, 77(2), 368-383.

McCubbins, M., Noll, R. and Weingast, B. R. (1989). Administrative Procedures as Instruments of Political Control. Journal of Law, Economics, and Organisations, 3(2), 243-277. OECD. (2002). Regulatory Policies in OECD Countries: From Interventionism to Regulatory Governance. Paris: OECD Publishing.

OECD. (2009). Regulatory Impact Analysis: A Tool for Policy Coherence. Paris: OECD Publishing.

OECD. (2012). Recommendation of the Council on Regulatory Policy and Governance. Paris: OECD Publishing.

OECD. (2013). Transparency and Integrity in Lobbying. Paris: OECD Publishing. OECD. (2014) OECD Regulatory Compliance Cost Assessment Guidance. Paris: OECD Publishing. 
Posner, E. A. (2001). Controlling Agencies with Cost-Benefit Analysis: A Positive Political Theory Perspective. University of Chicago Law Review, 68(4), 1137-1199.

Simon, H. A. (1955) A Behavioural Model of Rational Choice. The Quarterly Journal of Economics, 69(1), 99-118.

Sunstein, C. R. (1993). After the Rights Revolution: Reconceiving the Regulatory State. Cambridge, MA: Harvard University Press.

Van Schendelen, R. (2002). Machiavelli in Brussels: The Art of Lobbying the EU. Amsterdam: Amsterdam University Press. 